\title{
CFBC BOILERS-EFFECTIVE TECHNOLOGY
}

\author{
Sasikumar Santhanamarisamy \\ Design Engineer IV - Mechanical Engineering, \\ Fluor Daniel India Private Limited, \\ Infinity Tower B, $6^{\text {th }}$ Floor, DLF Cyber city, DLF Phase II, Gurugram-122002
}

\begin{abstract}
Advantage of using CFBC boilers instead of the PCC boiler in terms of efficiency and cost effective solution. In the other hand $\mathrm{CFBC}$ boilers provide the fuel flexibility, low emission of SOx \& NOx.
\end{abstract}

\section{INTRODUCTION}

CFBC (Circulating Fluidized Bed Combustion) as an alternative to Pulverized coal combustion (PCC) for power Generation. CFBC Boilers allows to burn wide range of Fuels (Coal. Lignite, Biomass, Petcoke etc.,) with different Fuel qualities. The key benefit of using the CFBC Technology is to meet the strict Environmental standards defined by Environmental Authority of a Particular area.

\section{General LAYOUT OF CFBC \& PCC BOILER}

\section{CFBC boiler:}

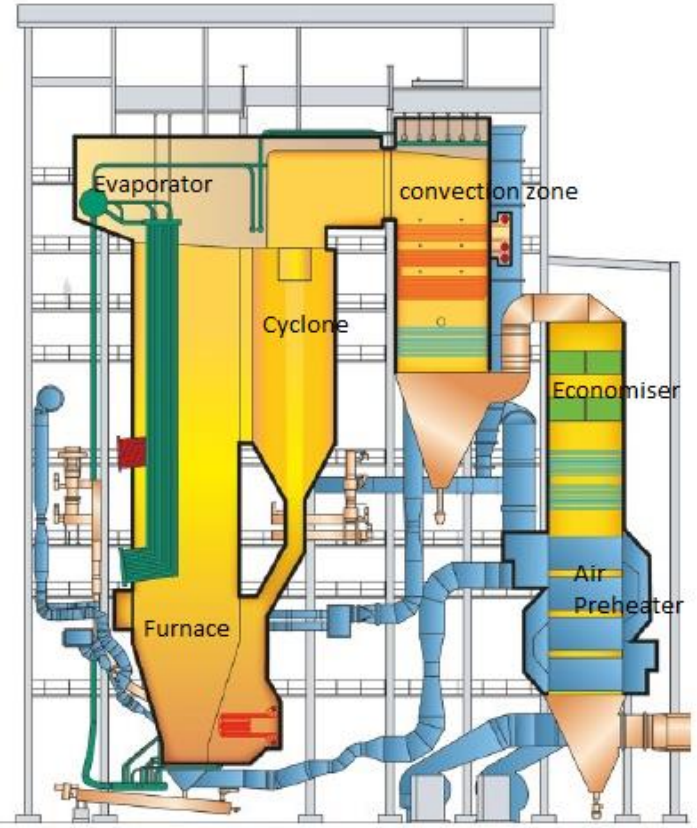

PCC Boiler;

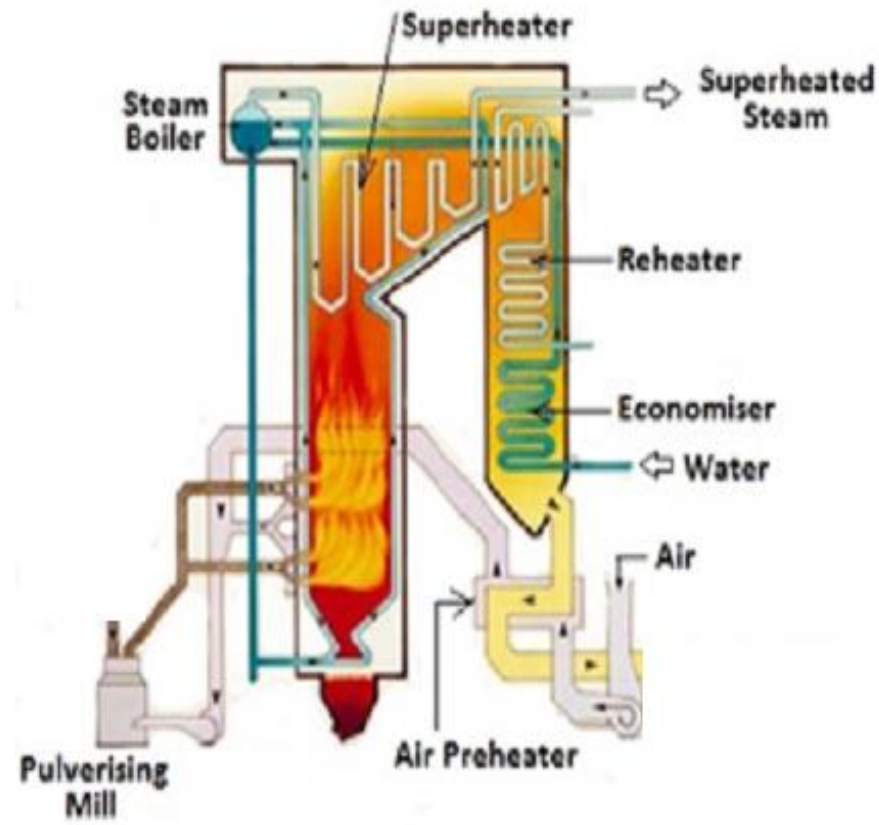

III. POWER AND STEAM FROM REFINERY:

Refineries with the delayed coke unit has the availability of Petcoke which can be used to produce power by integrating the Delayed Coke Unit with the CFBC Technology. The petcoke from the Delayed coker unit may have higher HHV with high Sulphur over $4 \%$ shall be used as fuel in CFBC boilers to produce the power and steam. Excess power and steam can be exported to Power grids.

\section{Advantage OF CFBC OVER CONVENTIONAL PCC BOILER}

As the bed temperature of the CFBC is below 900 deg. C (while PCC fired Boiler have the Bed temperature of 1400 deg. C) the NOx emission is considerably reduced and low NOx is achieved by introduction of Selective non Catalytic Reactor (SNCR). In addition of limestone to the furnace in turn reduces the emission of SOx Emission. Though the combustion temperature is low, the capture and Circulation of fuels provides the efficient heat transfer to the heating surface 


\section{International Journal of Engineering Applied Sciences and Technology, 2020 \\ Vol. 4, Issue 11, ISSN No. 2455-2143, Pages 272-273 \\ Published Online March 2020 in IJEAST (http://www.ijeast.com)}

area and long residence time for complete combustion and desulphurisation reaction.

Almost all the existing CFBC power generation units are small in capacity (300 MW) compared to $1000 \mathrm{MW}$ of PCC fired units and subcritical units and less efficiency than the Supercritical units. However in the last few years there were tremendous steps has been taken to scale up the CFBC Technology and design as the Supercritical units. Today 500 to $800 \mathrm{MW}$ Supercritical CFBC units are available in order to compete with the PCC Fired one.

\section{Comparison between CFBC Boiler and PC boiler}

\begin{tabular}{|c|c|c|}
\hline $\begin{array}{l}\text { S. } \\
\text { No. }\end{array}$ & PCC Boiler & CFBC Boiler \\
\hline 1 & $\begin{array}{l}\text { Combustion temperature } \\
\text { is of } 1250 \text { to } 1500^{\circ} \mathrm{C}\end{array}$ & $\begin{array}{l}\text { Combustion temperature is } \\
\text { of } 850 \text { to } 900^{\circ} \mathrm{C} \text {. }\end{array}$ \\
\hline 2 & $\begin{array}{l}\text { Furnace area Soot } \\
\text { blower requirement }\end{array}$ & $\begin{array}{l}\text { No requirement of soot } \\
\text { Blower at Furnace }\end{array}$ \\
\hline 3 & $\begin{array}{l}\text { Ash Slagging in furnace } \\
\text { due to high temperature }\end{array}$ & No Furnace Slagging \\
\hline 4 & $\begin{array}{l}\text { Higher Emission of SOx } \\
\text { and NOx }\end{array}$ & $\begin{array}{l}\text { Less Emission of SOx and } \\
\text { NOx due to circulation and } \\
\text { Complete combustion }\end{array}$ \\
\hline 5 & SCR requirement & $\begin{array}{l}\text { SNCR is enough for the } \\
\text { same type of Fuel }\end{array}$ \\
\hline 6 & Basically Coal fired & $\begin{array}{l}\text { Multi fuel Fired to adopt to } \\
\text { the changes in Fuel } \\
\text { availability }\end{array}$ \\
\hline 7 & More space occupied & $\begin{array}{l}\text { Less } \quad \text { space } \\
\text { compared to PCC } \\
\text { Boilers }\end{array}$ \\
\hline 8 & $\begin{array}{l}\text { Coal mills requirement } \\
\text { and Maintenance }\end{array}$ & No Coal mills requirement \\
\hline 9 & $\begin{array}{l}\text { More Electrical } \\
\text { Production Cost }\end{array}$ & $\begin{array}{l}\text { Less Electrical Production } \\
\text { Cost }\end{array}$ \\
\hline 10 & $\begin{array}{l}\text { Total installed cost is } \\
\text { more }\end{array}$ & Total installed cost is less \\
\hline 11 & $\begin{array}{l}\text { Requirement of Wet } \\
\text { Scrubber to control SOx } \\
\text { emission }\end{array}$ & $\begin{array}{l}\text { SOx emission is controlled } \\
\text { by adding limestone at } \\
\text { Furnace }\end{array}$ \\
\hline
\end{tabular}

\section{Advantages of CFBC Boilers:}

1. Fuel Flexibility- Biomass and Pet coke can also be burnt

2. Able to control emission of NOx and S0x under permissible limit.

3. Low unburnt carbon in ash- Higher combustion efficiency due to process recycle

4. Plant Higher availability - As more Flexibility in Fuel Usage
5. Low Installed Boiler Cost as plot size required is smaller than required for PCC fired one.

6. Low maintenance cost -CFBC Boilers does not require Fuel Mills, Fuel dryers and Fuel gas recirculation system.

\section{CONCLUSION}

In normal coal generation market, the practice is to have larger $600 \mathrm{MW}$ to $1000 \mathrm{MW}$ producing PCC fired Boiler. CFBC Boiler definitely will have advantage in terms of wide range of Fuels burning, low emission and low maintenance.

The fuel flexibility saves millions of operating cost savings over plant life. Co firing Biomass in CFBC shall bring the Renewable and carbon credit, as a waste market emerge and affordable imports of Fuels based on the seasons.

\section{REFERENCES}

[1] Dry FGD \& CFBC Boiler Seminar by Sumitomo Foster Wheeler at Hotel ITC Maurya, New Delhi September 12, 2019

[2] SOx- Sulphur Oxides : NOx- Nitrogen Oxides 